\title{
Anne Baba ve Ergenlerin Gözüyle Okul Sosyal Hizmet Uygulamalarına Duyulan İhtiyacın Belirlenmesi $^{1}$
}

\author{
DOI: $10.26466 /$ opus. 839688
}

*

\author{
Esra Kılıç Ceyhan * - Cengiz Özbesler* \\ * Dr. Öğr. Üyesi, Ankara Yıldırım Beyazıt Üniversitesi Sağlık Bilimleri Fakültesi, Ankara, Türkiye \\ E-Posta: shu esra@hotmail.com \\ ORCID: $\quad$ 0000-0002-9853-5788 \\ ** Prof, Dr., Ankara Yıldırım Beyazıt Üniversitesi Sağlık Bilimleri Fakültesi, Ankara, Türkiye \\ E-Posta: ozbesler@gmail.com \\ ORCID: 0000000213976913
}

Öz

Bireyin yaşamında önemli bir geçiş ve aynı zamanda kriz dönemi olarak adlandırılan ergenlik çă̆ı hem ergenin hem diğer aile bireylerinin uyum göstermesi gereken bir aşama olarak görülmektedir. Bu döneme özgü sorunlarda ergene ve ailesine sunulacak danışmanlık hizmetleri önem arz etmektedir. Uygulamalara ve literatüre bakıldı̆̆ında bu hizmetlerin okul odaklı çalışmalarla sunulduğu ve bu hizmeti sunan profesyoneller içinde okul sosyal hizmet uzmanlarının önemi vurgulanmaktadır. Bu çalışmada mevcut sistemde liselerde eğitim gören ergenlerin ve anne babalarının okul sosyal hizmet uygulamalarına ilişkin görüşlerini belirlemek ve bu uygulamalara duyulan ihtiyacı ortaya koymak amaçlanmıştır. Araştırmanın modeli karma yöntem olarak belirlenmiş ve konuyla ilgili ergenlerden nicel veriler, anne-babalardan nitel veriler elde edilmiştir. Araştırmanın nicel örneklemini lise öğrenimine devam eden 450 ergen, nitel çalışma grubunu ise 6 anne, 4 baba olmak üzere 10 ebeveyn oluşturmaktadır. Ergenlere uygulanan anket formu ve yarı yapılandırılmış görüşme formuyla annebabalarla yapılan görüşmeler neticesinde elde edilen verilere göre ergenlerin ve anne-babaların yaşadıkları sorunlara çözüm arayışında olduğu ve bu çözümlerden bir tanesinin de okullar aracılığıyla kendilerine danışmanlık sunulması ihtiyacı olduğu tespit edilmiştir. Bu noktada okul ortamlarında sosyal hizmet uygulamalarının hayata geçirilmesinin anne-baba ve ergenlerin bu taleplerine uygun bir hizmet olacağı anlaşılmış ve bununla ilgili öneriler sunulmuştur.

Anahtar Kelimeler: Ergenlik, aile, okul sosyal hizmeti.

\footnotetext{
${ }^{1}$ Bu çalışma "Anne Baba Ergen ilişkileri ile Aile Iş̧levleri Arasındaki ilişskinin Okul Sosyal Hizmeti Açısından incelenmesi " adlı doktora çalışmasının verileri kullanılarak hazırlanmıştır
} 


\title{
Determining the Need for School Social Work Practices from the Perspective of Parents and Adolescents
}

*

\begin{abstract}
Adolescence, which is an important transition in the life of the individual and also called the crisis period, is seen as a stage that both the adolescent and other family members should adapt to. Consultancy services to be offered to the adolescent and his family are important in problems specific to this period. Considering the practices and the literature, it is emphasized that these services are offered with schooloriented studies and the importance of school social workers among professionals who provide this service. In this study, it is aimed to determine the views of adolescents and their parents on school social work practices in the current system and to reveal the need for these practices. The model of the study was determined as a mixed method; quantitative data were collected from adolescents and qualitative data were obtained from parents. The quantitative sample of the study consists of 450 adolescents who continue their high school education, and the qualitative study group consists of 10 parents; 6 mothers and 4 fathers. According to the data obtained as a result of a questionnaire and semi-structured interview form applied to adolescents and interviews with parents, it was determined that adolescents and parents were in search of solutions to their problems and one of these solutions needed to be offered through school counseling. At this point, it was understood that the implementation of social work practices in school settings would be a service in line with these demands of parents and adolescents, and suggestions were made regarding this.
\end{abstract}

Keywords: Adolescence, family, school social work. 


\section{Giriş}

Bireyin yaşamında önemli bir geçiş aşaması olarak adlandırılan ergenlik dönemi hem ergenin hem de diğer aile bireylerinin uyum göstermesi gereken bir aşama olarak karşımıza çıkmaktadır. Ergenlik, ergendeki biyolojik, bilişsel ve sosyal değişimler nedeniyle ebeveynlerle ilişkinin çocukluk dönemindeki ilişkiden farklılaştığı bir dönemdir. Bu farklılaşma aile içi ilişkilerde çeşitli sorunlara yol açabilmektedir. Aile kurallarına uyma, evdeki günlük işler, akademik başarı, ev dışında geçirilen zaman gibi birçok konu anne-babayla ergen arasında soruna neden olabilmektedir (Smetana ve Gaines, 1999). Bu anlamda ebeveynlerin önünde zorlu görevler vardır; bir yandan ergenin eksik ya da doğru olmayan davranışlarını kontrol etmek için disiplin sağlamak; bir yandan da ergenlerin kendi dünyalarını keşfetmelerine olanak sağlamalıdırlar ve bunlar arasındaki dengeyi oluşturmak oldukça güç olabilmektedir (Matejevic, Jovanovic ve Lazarevic, 2014).

Ergen ve aile için bir geçiş ve kriz dönemi olarak adlandırılan bu yaşam döneminin farklı gelişimsel boyutlar ve ergenin içinde bulunduğu sistemler etrafında incelenmesi önerilmektedir. Bu noktada ekolojik yaklaşım, ergenin gelişimsel alanlarını bütüncül bir şekilde değerlendirme imkanı sunar. Ekolojik yaklaşım gelişim içinde olan ergeni çevresel bağlamlarda ele alarak, konuya bakış açısını genişletir ve içinde bulunduğu etkileşim süreçlerini, özellikle de ailenin çocuk üzerindeki etkilerini inceler (Bronfenbrenner ve Morris, 1998). Özellikle son yıllarda ergeni, 'aile, okul ve mahalle' bağlamlarında ele almanın ve çoklu etkileşim alanlarını incelemenin önemine vurgu yapılmaktadır (Cook, Herman, Phillips ve Settersten, 2002). Söz konusu çok boyutlu bakiş, uygulamalarında sistem ve ekolojik yaklaşımı kullanan sosyal hizmet mesleğini ön plana çıkarmaktadır.

Sosyal hizmetin ekolojik perspektifle çevresi içinde birey anlayışıyla bireyin içinde bulunduğu tüm sistemleri müdahale alanına dahil ettiği birey, aile, grup, toplum düzeyinde müdahaleler gerçekleştirdiği düşünüldügünde ergen, aile ve okul etkileşimlerini anlamada önemli bir işleve sahip olduğu düşünülmektedir. Nitekim Walker ergen ve ailelerine yönelik müdahalelerde bulunmak üzere sosyal hizmet uzmanlarını önermiştir (Walker, 2003). Walker, aile ve toplum düzeylerinde 
müdahalede bulunan sosyal hizmetin bu prensipleriyle, psikososyal müdahale bakış açısını bütünleştirmesi sonucu hem koruyucu hem tedavi edici fonksiyonlara sahip olduğunu belirtmektedir. Bu durum da sosyal hizmetin ergen ve aileyle çalışmada vazgeçilmez bir meslek olduğunu göstermektedir.

Sosyal hizmetin bu fonksiyonlarını yerine getirebilmesi için ergen ve ailelerine ulaşabileceği en önemli toplumsal kurumun okullar olduğu iddia edilmektedir (Gerrard, 2008). Zira halihazırda lise eğitimine devam eden çok sayıda ergen mevcuttur ve sosyal hizmet bakış açısı bu ergenlerin ailelerini de değerlendirme ve müdahale kapsamına almaktadır. Dolayısıyla bu noktada da dünyada hızla gelişen ülkemizde ise gelişmeyi bekleyen sosyal hizmetin okul ortamlarındaki uygulamaları konuyla ilgili çok boyutlu değerlendirme ve müdahale etme için önem arz etmektedir.

Okullarda sunulacak danışmanlık hizmetlerinin sadece öğrenci odaklı değil öğrencinin çevresini saran sistemleri (aile, arkadaş ve toplum) de kapsaması gerektiğini savunan araştırmacılar söz konusudur (Johnston ve Zemitzsch, 1988). Wetchler, öğrenci ve aile sorunlarının, aile ve okul sistemlerinin etkileşimli olarak müdahale sürecinde yer almasıyla çözülebileceğini savunmaktadır (Wetchler, 1986). Hinkle'de okullarda ailelere yönelik danışmanlık ihtiyacına dikkat çekerek bu konuda başarılı müdahaleler yapabilmek için öğrenciyi ve aileyi içinde bulunduğu sosyal çevre içinde değerlendirmenin önemini belirtmiştir (Hinkle, 1992). Konuyla ilgili Widerman, pozitif aile etkisinin okul başarısı üzerindeki etkisine vurgu yaparak okullarda aile odaklı çalışmalar yapılmasını önermiştir (Widerman ve Widerman, 1995). Long (1988) ve Lewis (1996)' te okullarda çocuk ve gençlere yardımcı olmak isteyen profesyonellerin aile odaklı çalışmalar yapmalarını savunmuşlardır.

Okullarda bu amaç etrafında çalışacak olan profesyoneller olarak sosyal hizmet uzmanları önerilmektedir. Constable, okul sosyal hizmet uzmanlarının birincil amacının bu doğrultuda mesleki çalışmalar yapmak olduğunu vurgulamıştır (Constable, 2008). Okul sosyal hizmet uzmanları aile odaklı çalışmaları ve çok boyutlu değerlendirme ve müdahale bakış açıları ile diğer profesyonellerden ayrılmaktadır. Ülkemizde sadece psikolojik danışman ve rehberlerin çalışmalarını yürüttüğü okul sisteminde ekip çalışması halinde çalışacak meslek elemanlarına ihtiyaç 
söz konusudur. Sadece psikolojik danışman ve rehberlerin olduğu rehberlik sistemimizin gerek sayı gerek nitelik bakımından talepleri karşılamadığı belirtilmektedir (Pişkin, 2006).

Okulda psikososyal destek sunan profesyoneller alan yazında ve uygulamalarda okul psikologları, okul psikolojik danışmanları, okul hemşireleri ve okul sosyal hizmeti gibi meslek elemanlarından oluşmaktadır ve her birinin mesleki sınırları bellidir. Okul psikolojik danışman ve rehberlerin çocukların akademik başarılarını yükseltme, kariyer planlamalarına yardımcı olma, bireysel çalışma planı oluşturma, program geliştirme, sağlıklı kişisel, sosyal gelişim göstermelerini sağlama gibi rol ve sorumluluklarına değinilmektedir (Tracy, Castro-Guillen ve Schraff, 2006). Okul psikologlarının ise çocukları duygusal, sosyal ve bilişsel olarak değerlendirme, psikometrik test yapma ve çocuğun bireysel özelliklerine uygun eğitim programlarına yönlendirme gibi rollerine dikkat çekilmektedir (Agresta, 2004). Tracy ve arkadaşları, okul sosyal hizmet uzmanlarının öğrencilerin öğrenmelerini etkileyebilecek aile, okul, toplum ve kişisel faktörlerini değerlendirme, danışmanlık yapma, vaka yönetimi ve krize müdahale gibi görevlere sahip olduklarını belirtmiştirler (Tracy vd., 2006).

Okul sosyal hizmet uzmanlarının bu kapsamdaki çalışmaları koruyucu-önleyici, rehabilite edici-iyileştirici, eğitici müdahaleleri kapsamaktadır. Ergen ve ailesi ise doğrudan uygulama alanı içine girmektedir. Bu bilgiler ışığında okul ortamlarında ergen ve ailelerine sunulacak hizmetlerin bir profesyonel ekip anlayışıyla gerçekleştirilmesinin önemi görülmektedir. ABD, İsveç gibi ülkelerde okul sosyal hizmet faaliyetleri bu ekibin çalışmaları doğrultusunda ilerlerken; bu faaliyetler Hong Kong'da sivil toplum kuruluşları aracılığıyla, Almanya'da ise gençlik refahı kurumları ile okul sistemi arasındaki işbirliği ile sunulmaktadır (Huxtable, 2012).

Bir geçiş ve kriz dönemi olarak adlandırılan ergenlik çă̆ında ergeni aile, okul, vb. sistemlerle ele almanın ve okullar aracılığılla sunulacak hizmetlerle aile ve ergenleri desteklemenin önemi ve bu noktada okul sosyal hizmetine yapılan vurgu alan yazındaki çalışmalarla ortaya konmuştur (Huxtable, 2012; Rowling, 2009 ve Allen-Meares ve Montgomery, 2014). Bu konuya dikkat çekmek amacıyla bu çalışmada anne-baba-ergenin gözüyle okul sosyal hizmetine duyulan ihtiyacı ortaya 
koymak planlanmıştır. Çalışmanın hedefi, nicel ve nitel araştırma yöntemleriyle elde edilen veriler ışığında ergen ve aile sorunlarına yönelik okul ortamında sunulabilecek hizmetleri değerlendirmektir.

\section{Materyal ve Yöntem}

\section{Araştırmanın Modeli}

Bu çalışmada karma araştırma modeli kullanılmıştır. Bu yaklaşımın temel varsayımı, araştırma problemini daha iyi anlamak için nicel veriler (istatistiki analizler) ile nitel verilerin (öyküler, kişisel deneyimler) birleştirildiği araştırmaların; bu yöntemlerden yalnızca herhangi birinin kullanıldığ1 araştırmalara kıyasla daha avantajlı olacağı yönündedir (Creswell, 2017).

Çalışmada yakınsayan paralel desen tercih edilmiştir. Nicel ve nitel aşamalar bağımsız bir şekilde, eş zamanlı ve ayrı ayrı gerçekleştirilmiş ve analiz edilmiştir. Çalışmanın sonunda yorumlama kısmında bu iki yöntemden elde edilen veriler birleştirilmiştir. Ergenlerden nicel araştırma yöntemleriyle veri elde edilirken; yarı yapılandırılmış görüşme formuyla anne-babadan nitel veri elde etmek, her iki araştırma türünden elde edilen verilerin ilişkilendirilmesi, benzerlik ve farklılıkların ortaya konmasını sağlamıştır. Aynı zamanda araştırmanın problemini farklı açılardan ölçerek zengin ve ayrıntılı bilgi sunma imkanı doğmuştur.

Araştırmanın nicel kısmında betimsel araştırma modeli kullanılmıştır. Araştırmanın nitel aşamasında ise fenomenolojik yaklaşım çerçevesinde anne- babaların okul sosyal hizmetiyle ilgili görüşlerine ilişkin derinlemesine bilgi toplamak amaçlanmıştır.

\section{Evren Örneklemi}

Araştırmanın evrenini, liselerde öğrenim gören 14-18 yaş aralığındaki ergenler oluşturmaktadır. Araştırmanın çalışma evreni ise Ankara İl'i Milli Eğitim Bakanlığı'na bağlı liselerde 2017- 2018 eğitim öğretim yılında öğrenim gören 14-18 yaş aralığındaki ergenleri kapsamaktadır. Araştırma örnekleminde toplam 490 lise öğrencisine ulaşılmıştır. Ancak 40 anketten elde edilen verilerin eksik ya da rastgele doldurulduğu tespit edilmiş ve 
araştırma veri setinden çıkarılmış, analizler için geçerli varsayımlar 450 ergen üzerinden sınanmıştır. Araştırmaya katılan ergenlerin \%51'i kadın $(n=220), \% 49^{\prime} u$ erkek $(n=211)$ olduğu görülmektedir. \%54,1'i 14-15 yaş aralığında $(\mathrm{n}=233), \% 45,9^{\prime} \mathrm{u}$ ise $16-17$ yaş aralığındadır $(\mathrm{n}=198)$. Sinıf düzeyleri 9 (\%32; $\mathrm{n}=138), 10 .(\% 30,4 ; \mathrm{n}=131), 11$ (\%37,6; $\mathrm{n}=162)$ sinıflardan oluşmaktadır.

Araştırmanın nitel çalışma grubu oluşturulurken amaçlı örneklem tercih edilmiştir. Nitel araştırmalarda büyük gruplarla çalışılmadığı ve genelleme amacı güdülmediği için örnekleme seçimi genellikle amaçlı olarak gerçekleşir (Glesne, 2012). Bu araştırmada da nitel veri elde etmek için amaçlı örneklem yöntemlerinden "rastgele" örneklem seçilmiştir. Amaçlı rastgele örneklem büyük bir hedef kitleden rastgele küçük miktarda birimler seçme işidir (Kemper, S., ve Teddlie, 2003). Nitel araştırmanın ulaşılabilir evrenini Ankara ilinde yaşayan ve lise öğrenimine devam eden çocuğu olan anne-babalar oluşturmaktadır. Araştırmanın çalışma grubunu ise amaçlı örneklem seçim yöntemlerinden olan kartopu yöntemiyle seçilen 6 anne ve 4 baba olmak üzere 10 katılımcı oluşturmaktadır. Araştırmacıya sağladığı kolaylık ve örnekleme ulaşılabilirliği kolaylaştırdığ 1 için bu yöntem tercih edilmiştir. Görüşme için örneklem sayısının az olmasının nedeni Yıldırım ve Şimşek (Yıldırım ve Şimşek, 2016)'e göre; verilerin ayrıntılı olması gerekliliğinden ve nitel araştırmalarda çok sayıda bireyin araştırma kapsamına dahil edilmesinin zorluğundan kaynaklanmaktadır.

\section{Araştırmada Kullanılan Veri Toplama Araçları}

Nicel Veri Toplama Araçları: Araştırmanın nicel kısmında örneklemi oluşturan ergenlere; araştırmacı tarafından geliştirilen "Ergenin kişisel özellikleri ile aile ve okul yaşamına ilişkin anket formu" uygulanmıştır. Nicel veri toplama araçlarından biri olan anketlerle bireylerin; demografik özelliklerinin bir konu hakkında ne bildiklerinin, bir konuya ilişkin davranışlarının ve bir konu veya objeye ilişkin duygu ve görüşlerinin belirlenebileceği ifade edilmektedir (Büyüköztürk, 2005). Bu çalışmada da okul sosyal hizmeti ihtiyacına ilişkin öğrencilerin görüşlerine ait sayısal veriler elde edilmeye çalışılmıştır. Bu amaçla araştırmanın problemi ekseninde alan yazın incelenerek, anket maddeleri oluşturulmuş, 
hazırlanan taslak anketle ilgili uzman görüşleri alınmış ve sonrasında bir ön uygulama gerçekleştirilerek anket sorularının anlaşılıp anlaşılmadığı test edilmiştir. Anketinin ilk kısmında ergenin yaş, cinsiyet, okul ve aile bilgileri gibi sosyo-demografik bilgiler ilişkin sorular bulunmaktadır. İkinci kısımda ise ergenlerin okul yaşamlarıyla ilgili bilgiler alınıp okul sosyal hizmetine dair görüşlerine "okulda ne tür sorunlar yaşadığı, yaşadığı sorunları çözmek için kime danıştığı, rehberlik servisine başvurma durumu ve bu servisi yararlı bulup bulmadığı, ailesiyle yaşadığı problemlerde okul ortamında ona yardımcı olacak profesyonellere olan gereksinimi ve yaşadığı sorunlarda kendisine nasıl yardımcı olunmasını istediği" şeklindeki sorularla ulaşılmak istenmiştir.

Nitel Veri Toplama Aracı: Yarı Yapılandırılmış Anne-Baba Görüşme Formu

Anne-baba görüşme yönergesi ergenlik ve sosyal hizmet alanlarında uzman kişilerden görüş alınarak ve literatür ışığında hazırlanmıştır. Form, anne-babanın sosyodemografik durumu, aile ve okul yaşamına ilişkin başlıklardan oluşmaktadır. Formda; "okulla işbirliği, okulda kimlerle işbirliği yapıldığı, anne babanın okul etkinliklerine katılımı (veli toplantısı,, anne baba eğitimi, seminer vb.), devamsızlıklar, okuldan kaçma, okulda yaşanan sorunlar ve çözüm önerileri, okul iklimi, akademik başarı, anne babanın akademik anlamda beklentileri, okulla ilgili konuları ergenle konuşabilme, okul rehberlik servisinden yararlanma, okuldan beklentiler, okul arkadaşlarıyla ilişkiler, öğretmenleriyle ilişkiler, okulun sağladığı sosyo-kültürel etkinliklere katılımı" gibi sorular yer almaktadır.

\section{Araştırmada Verilerin Toplanması}

Araştırmanın Etiği: Araştırmada kullanılacak materyalin hazırlanmasının ardından Ankara Yıldırım Beyazıt Üniversitesi Etik Kurul'undan gerekli izinler alınmıştır. Etik kurul izninin ardından Milli Eğitim Bakanlığı Ankara İlçe Milli Eğitim Müdürlüğü'nden araştırma için gerekli izinler alınmıştır. Araştırmanın saha çalışması sırasında veriler toplanmadan önce ergenlerden ve anne-babalardan bilgilendirilmiş onam alınmıştır ve çalışmaya gönüllü olarak katılımları sağlanmıştır. Ayrıca, nitel araştırmada anne-baba ve ergenlerin gerçek isimleri saklı tutulmuş ve rumuz kullanılarak araştırmada yer almıştır. 
Araştırmanın verileri Ekim 2017- Aralık 2017 ayları arasında toplanmıştır. Çalışmanın yapılacağı okullar önceden telefonla aranarak bilgilendirilmiş ve eğitim- öğretim faaliyetlerini aksatmadan veri toplama araçlarının uygulanması sağlanmıştır. Çalışmanın nitel veri toplama aracını araştırmacı yüz yüze görüşme tekniğiyle bizzat kendisi uygulamıştır.

Verilerin Analizi ve Yorumlanması: Araştırmanın nicel verileri SPSS 20 programına aktarılmış ve araştırmanın amaçları doğrultusunda istatistiksel analizler gerçekleştirilmiştir. Frekans sonuçları tablolar halinde belirtilmiş ve açıklamaları yapılmıştır. Araştırmanın nitel verilerinin analizinde ise öncelikle yapılan 10 görüşme yazıya aktarılmıştır. Katılımcıların görüşmelerdeki ifadeleri ve araştırmacının gözlemleri nitel verileri oluşturmuş ve bu veriler kodlar, kategoriler ve temalar oluşturularak içerik analizine tabi tutulmuştur.

\section{Bulgular ve Tartışma}

Çalışmanın bu kısmında araştırmadan elde edilen nitel veriler nicel verilerle ilişkilendirilmiş ve benzer çalışmalarla tartışılmıştır.

Nitel bulgularda "okul yaşamı" teması altında "anne babanın okulla işbirliği", "okulla ilgili yaşanan sorunlar", "okul rehberlik servisinden yararlanma" ve "okuldan beklentiler" kategorileri oluşturulmuş ve bu kategorilere ait alt kategoriler Tablo 1'de sunulmuştur. Bu verilere ilişkin açıklamalar nicel bulgularla bütünleştirilerek aşağıda sunulmuştur.

Nicel bulgulara bakıldığında; araştırmaya katılan ergenlerin yarısından fazlası $(\% 52,9)$, aile içi sorunların çözümünde okul ortamında kendilerine profesyoneller aracılığıyla yardımcı olunmasını talep etmişlerdir (Tablo 2). 
Tablo 1. Tema ve kategoriler

\begin{tabular}{lll}
\hline Tema & Kategoriler & Alt Kategoriler \\
\hline OKUL YAŞAMI & Anne-babanın & Veli toplantılarına katılım \\
& Okulla İşbirliği & Anne-babanın okuldan kopuşu \\
& Okulda davranış kontrolü \\
Okulla İlgili & Ders çalışma sorunu \\
Yaşanan & Okula gitmede isteksizlik \\
Sorunlar & Özel okul tercihi \\
& Öğretmen faktörü \\
& Akademik başarı odağında eğitim sistemi \\
& Okulla ilgili konuları ergenle konuşabilme \\
& Okul Rehberlik & Rehberlik servisini yararlı bulmama \\
& Servisinden & Rehberlik servisiyle ilgili bilgi sahibi olmama \\
& Yararlanma & Çocuklara uygun olmayan yaklaşım \\
& Rehber öğretmen sayı yetersizliği \\
& Mesleki sinırlar \\
& Okuldan & Okulda profesyonel destek ihtiyacı \\
Beklentiler & Akademik başarının yanında ruhsal anlamda \\
& sağlıklı çocuklar \\
& Bireysel danışmanlık ihtiyacı \\
& Ev ziyareti ihtiyacı \\
\hline
\end{tabular}

Tablo 2. Ergenlerin aile içi sorunların çözümünde okul temelli profesyonel yardım gereksinimine ilişkin görüşleri.

\begin{tabular}{llc}
\hline $\begin{array}{l}\text { Aile içi sorunların çözümünde okulda profesyonel yardım } \\
\text { gereksinimi }\end{array}$ & Sayı & \\
\hline $\begin{array}{l}\text { Okulda bana yardımcı olacak meslek elemanlarının bulunmasını } \\
\text { isterim }\end{array}$ & 228 & 52,9 \\
$\begin{array}{l}\text { Okulda bana yardımcı olacak meslek elemanlarının bulunmasını } \\
\text { istemem }\end{array}$ & 203 & 47,1 \\
Toplam & $\mathbf{4 3 1}$ & $\mathbf{1 0 0}$ \\
\hline
\end{tabular}

Ayrıca hangi konularda profesyonel yardım talep ettikleri sorusuna yanıtlarından bir tanesi 'sorunlarımla ilgili ailemle konuşulmasını isterim' şeklinde olmuştur (Tablo 3).

Bunun yanı sıra araştırmanın veri toplama aşamasında ergenlerin anketleri i doldururken 'bu konuları esas anne-babamızla da görüşün, onlara da uygulayacak mısınız?' gibi geri bildirimlerde bulundukları, kimi ergenin anketteki bazı kısımların fotoğrafını çekip 'anneme göstereceğim bunu' ifadesinde bulunduğu görülmüştür. 
Tablo 3. Ergenlerin sorunlarına yönelik okul ortamında profesyonel yardım talepleri.

\begin{tabular}{lll}
\hline $\begin{array}{l}\text { Ergenlerin sorunlarına okul ortamında profesyonel yardım } \\
\text { talebi }\end{array}$ & Sayı & $\mathbf{\%}$ \\
\hline Dertleşmek isterim, sorunlarıma çözüm bulsunlar & 61 & 32,11 \\
Bana yol göstersinler, fikir versinler & 41 & 21,58 \\
Anlayışlı, ilgili ve hoşgörülü bir uzmanın yanımda olmasını & 40 & \\
isterim & & 21,05 \\
Sorunlarımla ilgili ailemle konuşmasını isterim & 30 & 15,79 \\
Adaletli olsunlar, ayrım yapmasınlar & 18 & 9,47 \\
Toplam & $\mathbf{1 9 0}$ & $\mathbf{1 0 0}$ \\
\hline
\end{tabular}

Bu veriler ergenlerin aileleriyle, anne-babalarıyla yaşadıkları sorunlara çözüm arayışında olduğunu ve okul ortamında sağlanacak olan danışmanlık hizmetini de bu çözüm noktalarından bir tanesi olarak algıladıkları görülmektedir. Ergenlerin bu görüşünü anne-babaların ifadeleri de desteklemektedir. "Okuldan beklentiler" kategorisi altında araştırmaya katılan anne-babalar okullar aracılığıyla kendilerine ve ailelerine bireysel ve aile düzeyinde danışmanlık verilmesini sıkça vurgulamışlardır.

"Eşime nasıl davranmalıyım ya da çocuklarıma nasıl davranmalıyım ki ilişkilerimiz daha verimli olsun" bu konularda yönlendirilmek isterdim. Keşke okullarda böyle profesyoneller olsa" (Kadriye)

"Kızımla ilişkim konusunda, aile ilişkilerinde ne yapmam gerekir onu konuşmak isterdim. Konuşmak bile insanı rahatlatıyor. Şurada sizinle konuşurken bile kaç nokta yakalıyor insan" (Hale)

"Psikolojik danışman ve rehber öğretmenler akademik başarıyla ilgili çalışıyor, aileyle görüşüyor belki ama bununla iş bitmiyor. Çocuklarm ruhlarına da inmek gerekiyor, tek akademik başarı değil. Burada devreye sosyal hizmet girebilir. İnşallah bunlar hayata geçerse". (Deren)

Literatür incelendiğinde okullarda danışmanlığın farklı boyutlarına değinildiği görülmektedir. Bunlardan bir tanesi okul sosyal hizmetinin de odağını oluşturan aileyle çalışma boyutudur. Konuyla ilgili Widerman, pozitif aile etkisinin okul başarısı üzerindeki etkisine vurgu yaparak okullarda aile odaklı çalışmalar yapılmasını önermiştir (Widerman ve Widerman, 1995). Long (Long, 1988) ve Lewis (Lewis, 1996)' te okullarda çocuk ve gençlere yardımcı olmak isteyen profesyonellerin aile odaklı çalışmalar yapmalarını savunmuşlardır. 
Bu noktada bireyi yaşadığı çevre ve aile içerisinde değerlendiren ve müdahale planlarını bu çerçevede sunan sosyal hizmet mesleğinin okul ortamlarında aile odaklı çalışmalar yapmasının önemi ortaya çıkmaktadır. Araştırmaya katılan anne-babalar ifadelerinde bu ihtiyaca dikkat çekmişlerdir.

"Bence psikolojik danışman ve rehber öğretmenler kadar sosyal hizmet uzmanlarının da okullarda çalışması şart. Çok gerekli bu. İnşallah zaman içerisinde bu gerçekleşir. Şu eksik bu eksik diye eleştiren bir kadın olmak istemiyorum ama MEB'de eksiklikler var. MEB çok önemli, adı üstünde eğitim"(Deren)

Okullarda sunulacak danışmanlık hizmetlerinin sadece öğrenci odaklı değil öğrencinin çevresini saran sistemleri (aile, arkadaş ve toplum) de kapsaması gerektiğini savunan araştırmacılar söz konusudur (Johnston ve Zemitzsch, 1988). Wetchler, öğrenci ve aile sorunlarının, aile ve okul sistemlerinin etkileşimli olarak müdahale sürecinde yer almasıyla çözülebileceğini savunmaktadır (Wetchler, 1986). Hinkle'de okullarda ailelere yönelik danışmanlık ihtiyacına dikkat çekerek bu konuda başarılı müdahaleler yapabilmek için öğrenciyi ve aileyi içinde bulunduğu sosyal çevre içinde değerlendirmenin önemini belirtmiştir (Hinkle, 1992). Okullarda bu amaç etrafında çalışacak olan profesyoneller olarak sosyal hizmet uzmanları önerilmektedir. Constable, okul sosyal hizmet uzmanlarının birincil amacının bu doğrultuda mesleki çalışmalar yapmak olduğunu vurgulamıştır (Constable, 2008). Çünkü okul sosyal hizmet uzmanları uygulamalarında ekolojik ve sistem yaklaşımını kullanarak çocuğu, genci içinde bulunduğu aile, okul, mahalle, arkadaş ortamlarında incelemektedir. $\mathrm{Bu}$ mesleki bilgi ve beceriler, okul sosyal hizmet uzmanlarını okuldaki diğer profesyonellerden ayırmaktadır. Nitekim araştırmaya katılan anne-babalar şuan mevcut durumda sadece psikolojik danışman ve rehberlerin yer aldığı okul ortamında bu meslek alanının sınırlılıklarına dikkat çekerek ailelerle çalışacak profesyonellere olan ihtiyacı ortaya koymuşlardır. "Okul rehberlik servisinden yararlanma" kategorisindeki kodlardan biri olan "mesleki sınırlar" başlı̆̆ı altında aşağıdaki ifadeler kullanılmıştır:

Rehberlikten akademik başarı, şu yazılıdan kaç aldı, biraz daha etüt yapabilir miyiz gibi bildirimler alıyoruz sadece. (Deren) 
Ben okulda başka profesyonellerinde olmasın isterim. Rehberlik hocasının aileyle ilgili konularda fayda vereceğini tahmin etmiyorum. Rehberlik her okulda var ama onlarm mesleki sınırları belli. Uzmanların ailelerle bir araya gelmesi çok önemli. (Kenan)

Katılımcılar, psikolojik danışman ve rehberlerin sadece akademik başarı üzerinde yoğunlaşan mesleki sınırları olduğunu belirterek, aileyle ilgili çalışmalarda yeterli faydayı göreceklerini düşünmediklerini belirtmişlerdir. Katılımcıların bu söylemleri literatür tarafından desteklenmektedir. Alan yazında ve uygulamalarda psikolojik danısman ve rehberlerin çocukların akademik başarılarını yükseltme, kariyer planlamalarına yardımcı olma, bireysel çalışma planı oluşturma, program geliştirme, sağlıklı kişisel, sosyal gelişim göstermelerini sağlama gibi rol ve sorumluluklarına değinilmektedir (Tracy vd., 2006)

Araştırmaya katılan ergenlerin rehberlik servisini yararlı bulmama nedenlerinin büyükten küçüğe 'bizimle ilgilenmiyorlar $(\% 31,6)$ ', 'sorunlara çözüm bulmuyorlar $(30,3)$ ', 'hiç gitmedim $(18,4)$ ' şeklinde siralandığ 1 görülmektedir. $\mathrm{Bu}$ sonuç, ergenlerin bu servisle ilgili beklentilerinin karşılanmamasıyla ilişkilendirilebilir. Çünkü ergenler kendilerine sorulan "okul ortamında sorunlarınızı çz̈zmede size nasıl yardımo olunmasını istersiniz?" sorusuna 'dertleşmek isterim, sorunlarıma çözüm bulsunlar', 'bana yol göstersinler, fikir versinler', 'sorunlarımla ilgili ailemle konuşulmasını isterim' şeklinde yanıtlar vermişlerdir. (Burada öğrenciler tarafından 'çözüm' olarak kastedilenin, profesyonel müdahalede; ergenin ve ailenin sorunlarıyla baş etmede kullanabileceği potansiyellerini açığa çıkarmak ve kendi çözümlerini bulmalarına yardımcı olmak şeklinde gerçekleştiğini belirtmekte fayda vardır). Dolayısıyla psikolojik danışman ve rehberlerin mesleki sınırları ve iş yükleri düşünüldüğünde öğrencilerin ruhsal dünyalarında yaşadıkları sorunları dile getirebilecekleri başka profesyonellere ihtiyaç görülmektedir. Anne-babalar da bu ihtiyaca dikkat çekmiş ve okul ortamının çocuklarına akademik başarının yanında sağlıklı ruhsal yaşam kazandırmasını arzuladıklarını dile getirmişlerdir.

"Psikolojik danışman ve rehberler akademik başarıyla ilgili çalışıyor, aileyle görüşüyor belki ama bununla iş bitmiyor. Çocuklarm ruhlarna da inmek gerekiyor, tek akademik başarn değil. Burada devreye sosyal hizmet girebilir. İnşallah bunlar hayata geçerse". (Deren) 
Bu noktada ergenlerin okulda karşılaştıkları sorunlara yönelik neler yaptıkları sorusuna bakıldığında; bu soruya verdikleri ilk iki cevabın 'hiçbir şey yapmıyorum' ve 'kendi kendime çözüm üretmeye çalışıyorum' şeklinde olduğu görülmektedir (Tablo 4).

Tablo 4. Ergenlerin okulda karşılaştıkları sorunlara çözüm önerileri.

\begin{tabular}{lll}
\hline Okulda karşılaştığı sorunlara çözümleri & Sayı & $\%$ \\
\hline Hiç bir şey yapmıyorum & 48 & 20,78 \\
Kendi kendime çözüm üretmeye çalışırım & 44 & 19,05 \\
Öğretmenlerimden yardım isterim & 43 & 18,61 \\
Empati kurarım, karşımdakiyle konuşurum & 37 & 16,02 \\
Aileme ve çevremdeki insanlara danısırım & 27 & 11,69 \\
Daha çok ders çalışırım & 13 & 5,63 \\
Kavga ederim & 11 & 4,76 \\
Okulu bırakırım & 8 & 3,46 \\
Toplam & $\mathbf{2 3 1}$ & 100 \\
\hline
\end{tabular}

Yukarıda da belirtildiği gibi ergenler bir yandan sorunlarına çözüm arayışında, birilerinin onları dinlemesini beklerken; diğer yandan bu beklentilerini karşılayacak bir sistemin olmayışı nedeniyle sorunları karşısında ya hiçbir şey yapamadıklarını ya da sorunlarla tek başına mücadele ettiklerini belirtmişlerdir. Dolayısıyla ergenlerin rehberlik servisine başvurma oranın da \%33,2 şeklinde küçük bir oran olduğu görülmektedir (Tablo 5).

Tablo 5. Ergenlerin rehberlik servisine yönelik algıları.

\begin{tabular}{lll}
\hline Rehberlik servisine başvurma & Sayı & \% \\
\hline Başvurmuyorum & 288 & 66,8 \\
Başvuruyorum & 143 & 33,2 \\
Rehberlik servisini yararlı bulma durumu & & \\
Olsa da olur olmasa da olur & 174 & 40,4 \\
Yararlı & 173 & 40,1 \\
Hiçbir yararı yok & 84 & 19,5 \\
Toplam & $\mathbf{4 3 1}$ & $\mathbf{1 0 0}$ \\
\hline
\end{tabular}

Ergenlerin rehberlik servisine başvurmayı yüksek oranda tercih etmemeleriyle ilgili bulgular, anne-babaların "okul rehberlik servisinden yararlanma" kategorisi altında toplanan ifadeleriyle birlikte ele alınabilir. Anne-babalar da çocuklarıyla yaşadıkları sıkıntılarda okullarda danışabileceği bir birime ihtiyaç duyduklarını; ama rehberlik servisinin 
bu konuda yarar sağlamayacağını ya da bu servisle ilgili bir fikir sahibi olmadıkları için buraya başvurmadıklarını belirtmişlerdir.

"Rehberlik servisinden yardım almadım ama çok düşündüm gitmeyi. Ama gitmedim niyeyse? Kızımla yine böyle kavgalı olduğumuz sabahlardan biriydi. Rehberliğe mi gitsem diye düşündüm. Onunla da konuşurlar, benimle de konuşurlar diye düşündüm ama gidememişsim. Hiçbir fikrim yok işte gitmediğim için". (Hale)

Nitel bulgulardaki "anne babanın okulla işbirliği" kategorisindeki söylemlerden de anlaşılabileceği gibi, anne-babaların okulda başvurabileceği, yararlanabileceği bir danışmanlık biriminin olmayışı okul-aile işbirliğinin sadece veli toplantılarıyla sınırlı kalmasına neden olabilmektedir.

"Biz toplantıdan toplantıya okula gidiyoruz. Öğretmenler gelin diyor aslında ama lisede artık çocuklar büyüdü, okula gitmek ayıp kaçacakmış gibi geliyor. Benim açımdan değil de çocuk açısından böyle hissedilecekmiş gibi geliyor. Bunu düşündüğüm için toplantıdan toplantıya gidiyorum". (Selma)

Durumun böyle oluşu ve anne-babaların, çocuklarının yaşı ilerledikçe kendilerinin okulla bağının kopması; ergenlik dönemiyle birlikte artan ergenin kişisel ve gelişimsel sorunları ile anne-baba-ergen ilişkileri sorunlarının okul ve aile işbirliği çerçevesinde çözümüne olanak tanımamaktadır. Bu konuda Walker, ergen ve aileleriyle çalışmak üzere okul sosyal hizmet uzmanlarını önererek, sosyal hizmet uzmanlarının aile ve toplum odaklı çalışmalarının önemine dikkat çekmiştir (Walker, 2003).

Okul sosyal hizmetinin soruna yönelik müdahale odaklı çalışmaları, rehabilite edici-iyileştirici görevlerini oluşturmaktadır. Ancak okuldaki rolleri sadece bu hizmetle sinırlı kalmamaktadır. Güçlendirme yaklaşımını kullanarak ergenin ve ailenin sahip olduğu potansiyel güçleriyle ilgili farkındalık sağlayabilir. Ayrıca çocuklara ve ailelere koruyucu-önleyici, eğitici-destekleyici hizmetler de sunmaktadır. Annebabalar "okuldan beklentiler" kategorisi altındaki anlatılarında bu ihtiyaçtan bahsetmekte ve ergenlik öncesinde kendilerine sunulacak danışmanlık hizmetlerinin olması durumunda ergenlik döneminin annebaba-ergen ilişkileri açısından daha sağlıklı atlatılacağını belirtmektedirler.

"Domino taşlarna benzetiyorum ben durumu. Ufak bir dokunuşla her şeyi değiştirebiliyorsunuz. İşte küçük yaşlardan itibaren okullarda sosyal hizmet 
uzmanlarımın olması ailelerin daha bilinçli olmasını sağlayacak. Çünkü ergenlik öncesinde bunlar bilinirse çok rahat ergenlik yaşayacak çocuklarımı.." (Deren)

Ayrıca araştırmaya katılan bir baba, aynı kategori altında kendi okul deneyimlerini paylaşırken bir öğretmenin evlerine olan ziyaretini anlatırken adeta sosyal hizmetin mesleğe özgü önemli yöntemlerinden biri olan "ev ziyaretleri" kavramından bahsetmiştir. "Benim eskiden Almanca öğretmenim vardı. Onu hiç unutmam mesela. Taaa evimize kadar gelmişti. Almanca öğretmeni... düşün yani bir tane ders öğretmeni. Şimdi var mi öyle bir şey? Demek ki hoca, çocuklarla bağlantı, ilişki ne kadar kurmak istiyor. Bir şeyler yapmak istiyor diye düşünmüştüm. Öğrenciye bir şey kazandıracak. Yoksa taaa evime kadar niye gelsin. Bana değer verdiğini hissetmiştim. Ben bu olayı hiç unutmam." (Ayhan). Bir öğretmenin evine kadar gelmiş olmasının kendinde yarattığ1 değerlilik hissinden bahsetmesi, günümüz koşullarında da ergenlerin ilgi, sevgi, değerlilik ihtiyacını karşılama ve ergenleri ailesi, çevresi içinde değerlendirme yapma açısından ev ziyaretlerinin önemini ortaya koymaktadır.

Dawson ve McHugh, zorlaşan öğretmen- ebeveyn iletişimini kolaylaştırmak ve çocukların davranışlarını değiştirmek için aile sistemi yaklaşımının bir parçası olarak "ev ziyaretleri" nin yapılabileceği konusunda örnekler vermektedir (Dawson ve McHugh, 1987). Campbell ve Mitchell, aileyi güçlendirmek ve karşılaştığı güçlüklerin üstesinden gelmek için ev ziyaretleri yaparak güçlendirme yaklaşımını kullanmanın önemine dikkat çekmiştir(Campbell ve Mitchell, 2007).

Son olarak şunu belirtmekte fayda vardır. Bu çalışmada rehberlik servisi, ergenlerin ya da ailelerinin bu birime başvurup başvurmama durumuna göre değerlendirilmiştir; bunun dışında kuşkusuz okul ortamında rehberlik hizmetlerinin geniş kapsamda yürütüldüğü ilgili yönetmelikte belirtilmektedir. 2017'de MEB tarafından yayınlanan yönetmelikte; rehberlik hizmetlerinin alanlarına göre (eğitsel, mesleki, kişisel), birey sayısına göre (bireysel, grup), öğretim kademelerine göre rehberlik hizmetleri ile bireyi tanıma, psikolojik ölçme araçlarının uygulanması, yönlendirme ve yerleştirme, psikososyal koruma, önleme ve krize müdahale hizmetleri, danışmanlık tedbiri uygulanması ve aile rehberliği şeklinde sıralanan faaliyetleri bulunmaktadır (MEB, 2017).

$\mathrm{Bu}$ yönetmelikte birçok faaliyetten sorumlu meslek elemanının rehberlik öğretmeni olduğu belirtilmektedir. Bunun dışında idarecilerin, 
sınıf öğretmenlerinin, özel eğitimcilerin görev tanımları yapılmış; sosyal çalışmacı (sosyal hizmet uzmanı), psikolog, vb. profesyonellere ise gerektiğinde başvurulacağı belirtilmiştir. Okulda yürütülen faaliyetlerin birçoğunun rehberlik öğretmeni aracılığıyla yapılıyor olması bu profesyonellere fazla ve mesleki sınırlarının dişında da sorumluluk verilmesi riskini doğurabilir. Hele de ülkemizde mevcut durumda 'sadece psikolojik danışman ve rehberlerin olduğu rehberlik sistemimizin gerek sayı gerek nitelik bakımından talepleri karşılamadığı (Pişkin, 2006) bir psikolojik danışmana düşen öğrenci sayısının fazla olduğu (Korkut, 2007) belirtiliyorken bu duruma dikkat çekmek önem arz etmektedir.

$\mathrm{Bu}$ noktada okul ortaminda yapilması gereken faaliyetler incelendiğinde bu hizmetlerde yer alacak profesyonellerin çeşitliliğinin artırılmasına dikkat çekmek gerekmektedir. Özellikle 'çalışma boyunca vurgulanan sosyal hizmetin aile odaklı çalışmalar yapması, ergenin ve ailesinin refahını engelleyebilecek risk faktörlerini değerlendirme (yaşanılan ortamın, evin, mahallenin, okul, arkadaş çevresinin incelenmesi, madde kullanım riski, şiddet eğilimi, vb.), toplumdaki kuruluşlarla işbirliği halinde çalışma, sosyal hizmetin birincil alanlarıyla ilgili faaliyetleri yürütme (koruma altındaki çocuğun okul uyumu ya da danışmanlık, koruma tedbiri, vb. uygulamaların yürütülmesi), istismar ve ihmal gibi çocuğun gelişimi için risk oluşturan durumların tespiti ve bununla ilgili işlemlerin yürütülmesi' gibi alanlarda bir ekip çalışmasına ve rehberlik öğretmeninin yanı sıra okul sosyal hizmet uzmanlarının da görevlendirilmesine ihtiyaç duyulmaktadır.

\section{Sonuç ve Öneriler}

Vakitlerinin büyük kısmını okullarda geçiren ergenlere önemli ve hassas bir geçiş aşaması olan bu dönemde danışmanlık yapmak önem arz etmektedir. Nitekim hem ergenler hem de anne-babalar bu çalışmada bu isteklerini dile getirmişlerdir. Ergenlerin ve anne-babaların yaşadıkları sorunlara çözüm arayışında olduğu ve bu çözümlerden bir tanesinin de okullar aracılığıyla kendilerine danışmanlık sunulması ihtiyacı olduğu tespit edilmiştir. Bu kapsamda okullardaki danışmanlık sisteminin güçlendirilmesi gerekmektedir. 
Ülkemizde mevcut okul sisteminde rehberlik anlamında sadece psikolojik danışman ve rehberler bulunmaktadır. Bunun yanında çalışmanın bir çıktısı olarak dünyada benzer uygulamaları görülen, okullarda ergen ve ailelere disiplinler arası işbirliğiyle yaklaşacak bir psikososyal ekip önerilmektedir. Bu anlamda okullarda böyle bir ekibin varlığı ergen ve aile sorunlarını anlamada ve müdahalede geniş bir çerçeve çizecek ve önemli bir toplumsal kurum olan ailelerin güçlenmesini sağlayacaktır. $\mathrm{Bu}$ müdahaleler kapsamında "ev ziyaretlerinin" yapılması önerilmektedir. Böylece, aileleri yaşadıkları ortamda gözlemleme fırsatı elde edilebilir ve daha doğru tespitlerle etkili müdahale planları hazırlanabilir

Araştırmanın bir başka sonucu olan anne-babaların okul ortamının çocuklarına hem akademik başarı getirmesi, hem de onlara sağlıklı bir ruhsal yaşam kazandırması istekleri okul sosyal hizmetiyle gerçekleşebilir. Ergenin ilgi alanları ve anne-babanın ondan beklentileriyle ilgili aile görüşmeleri yapılabilir, akademik başarının dışında ergenin fiziksel, duygusal, sosyal ve ahlaki gelişiminin önemine ilişkin anne-babalarda farkındalık oluşturulabilir. Ayrıca ergenin sorumluluk ve beceri kazanmasında bilişsel-davranışçı terapi teknikleri kullanılabilir.

Tüm bu uygulamalarda önemli olan nokta; çocuk, ergen ve ailelerin refahı için aile-okul-toplum işbirliğiyle bir hizmet ağının oluşturulmasıdır. Bu bakımdan ülkemizde de kültürel ve eğitim sistemimize uygun bir şekilde okul sisteminin içinde ya da diğer bakanlıklar (Aile ve Sosyal Hizmetler Bakanlığı, vb.) aracılı̆̆ıyla okul sosyal hizmet uzmanlarının bu alanda faaliyet göstermesi önem arz eden bir durumdur.

Ayrıca okullarda görev alacak sosyal hizmet uzmanlarının lisans eğitimlerinin üzerine psikoterapi, oyun terapisi, çocuk, ergen, aile ve çift danışmanlığına ilişkin bilgi ve becerilerini geliştirmesi önerilmektedir. Bu amaçla hizmet içi eğitim ve sertifika programlarına katılmaları yürüteceği faaliyetlerin niteliği açısından önem arz etmektedir.

Araştırmanın bir diğer önemli sonucu, bugüne kadar ergen ve ailelerine yönelik nitel odaklı çalışmaların az sayıda olması göz önünde bulundurulduğunda; konuyla ilgili araştırmalara metodolojik eğilim açısından bu çalışma örnek teşkil edebilir. Diğer taraftan bu çalı̧̧ma 
sadece anne-baba ve ergen örneklemiyle sınırlı kalmıştır. Gelecekteki çalışmalarda; bu örneklemle birlikte okul sistemi içinde yer alan öğretmen ve idarecilerin görüşlerinin de alındığı daha kapsamlı araştırmaların yapılmasının literatüre katkı sağlayacağı düşünülmektedir. 
EXTENDED ABSTRACT

\title{
Determining the Need for School Social Work Practices from the Perspective of Parents and Adolescents
}

\author{
Esra Kılıç Ceyhan - Cengiz Özbesler \\ Ankara Yıldırım Beyazıt University
}

As an important transition in the life of the individual and also called the crisis period, adolescence is seen as a stage in which both the adolescent and other family members must adapt. Counseling services to be offered to adolescents and their families in problems specific to this period are important. When we look at the practices and the literature, it is emphasized that these services are provided with school-oriented studies and the school social workers among the professionals who provide this service are considered important. In this study, it is aimed to determine the opinions of high-school adolescents and their parents about school social work practices in the current system and to reveal the need for the social work practices.

Mixed method is adopted in the study; quantitative data were collected from the adolescents and qualitative data were obtained from the parents. The quantitative sample of the study consists of 450 adolescents who continue their high school education, and the qualitative study group consists of 10 parents, 6 mothers and 4 fathers. Convergent parallel pattern was preferred in the study. Quantitative and qualitative stages were carried out and analyzed independently, simultaneously, and separately. The data obtained from these two methods were combined in the interpretation part at the end of the study. While obtaining data from adolescents with quantitative research methods; qualitative data were obtained from the parents with a semi-structured interview form, and the correlation of the data obtained from both types of research enabled the similarities and differences to be revealed. At the same time, it has become possible to present rich and detailed information by measuring the problem of the research from different angles. The descriptive research model was used in the quantitative part of the study. In the qualitative 
phase of the study, it was aimed to gather in-depth information about the views of parents on school social work within the framework of the phenomenological approach. The quantitative data of the research were transferred to the SPSS 20 program and statistical analyzes were carried out in line with the purposes of the research. Frequency results are given and explained in tables. In the analysis of the qualitative data of the research; firstly 10 interviews were transcribed. The information provided by the interviewees and the researcher's observations were used as qualitative data sources. Content analysis was carried out using existing resources. When the data were analyzed, it was determined that adolescents and parents were in search of solutions to the problems they experienced, and one of these solutions was the need to offer them counseling through schools.

In the current school system in our country, there are only psychological counselors and guides in terms of guidance. In addition, as an outcome of the study it is recommended that a psychosocial team should be established, which has similar practices in the world, and which will approach adolescents and families in schools with interdisciplinary cooperation. It is recommended that academic counseling, career planning, psychological counselors and guidance, applying psychometric tests, etc. fall within the professional boundaries of psychologists; but the 'school-family-society' focused studies should be carried by social workers. The role of school social workers in this context includes preventive-protective, rehabilitative-remedial and educational interventions. Adolescents and their families directly fall into the field of social work application. In this sense, the existence of such a team in schools will provide a wider framework for understanding and responding to adolescent and family problems, and will strengthen families, which is an important social institution.

When the activities to be done in the school environment are examined, it is necessary to draw attention to increasing the diversity of professionals who will take part in these services. In particular, it was emphasized throughout the study that the social work should carry out familyoriented studies, evaluate the risk factors that may prevent the welfare of the adolescent and his family (examination of the living environment, home, neighborhood, school, friend circle, risk of substance use, violence 
tendency, etc.), working in cooperation with institutions in the society, and there is a need for a team work, in addition to counselor, there must be social workers in areas such as carrying out activities related to the primary areas of social work (school adaptation of the child under protection or carrying out applications such as counseling, protection measures, etc.), detecting situations that pose a risk for the development of the child, such as abuse and neglect, and carrying out related procedures.

While school social work activities progress in line with teamwork in countries such as the USA and Sweden; these activities are offered in Hong Kong through non-governmental organizations and in Germany through cooperation between youth welfare institutions and the school system. The important point in all these applications is the establishment of a service network for the welfare of children, adolescents and families with the cooperation of family-school-society. In this respect, it is important for school social workers to operate in this field either within the school system or through other ministries (Ministry of Family, Labor and Social Services, etc.) in accordance with our cultural and educational system in our country.

In addition, it is recommended that social workers who will work in schools should develop their knowledge and skills on psychotherapy, play therapy, child, adolescent, family, and couple counseling after their undergraduate education. For this purpose, their participation in inservice training and certificate programs is important in terms of the quality of the activities they will carry out.

Another important result of the research is that considering the limited number of qualitative studies on adolescents and their families; this study can serve as an example for research on the subject to increase methodological flexibility. On the other hand, this study was limited to only the sample of parents and adolescents. In future studies, it is thought that conducting more comprehensive studies, including the opinions of teachers and administrators in the school system, will contribute to the literature. 


\section{Kaynakça / References}

Agresta, J. (2004). Professional role perceptions of school social workers, psychologists and counselors. Child and Schools, 26(3), 151-163.

Allen-Meares, P. and Montgomery, K. L. (2014). Globel trends and school-based social work. Child Sch, 36(2), 105-112.

Bronfenbrenner, U. and Morris, P. (1998). The ecology of developmental process. İçinde In Handbook of Child Psychology, Theoretical Models of Human Development (p.993-1028). New York: Wiley.

Büyüköztürk, Ş (2005). Anket geliştirme. Türk Eğitim Bilimleri Dergisi, 3(2), 133148.

Campbell, L. and Mitchell. (2007). Victorian Family- Support Services in Retrospect: Three Decades of Investment. Challenge and Achievement.Australian Social Work, 60(3).

Constable, R. (2008). The role of the social worker, school school work practice, policy and research. In History and General Perspectives on Social Work. (p.3-29). Lyceum boks inc.

Cook, T., Herman, M., Phillips, M. and Settersten, R. (2002). Some ways in which neighborhoods, nuclear families, friendship groups, and schools jointly affect changes in early adolescent development. Child Development, 73, 1283-1309.

Creswell, W. J. (2017). Karma yöntem araştırmalarına giriş. (P. D. M. Sözbilir, Ed.). Ankara: Pegem Yay.

Dawson, N. and McHugh, B. (1987). Learning to talk to parents. British Journal of Special Education, 14(3), 119-121.

Gerrard, B. (2008). School- Based family counseling: Overview, trends, And recommendations for future research. International Journal for SchoolBased Family Counseling, 1(1),1-30.

Glesne, C. (2012). Nitel araştırmaya giriş. Ankara: Anı Yay.

Hinkle, S. C. (1992). Family Counselling in the Schools: ERIC, Clearing House on Counseling and Personnel Services, 27(4), 252-257.

Huxtable, M. (2013). A Globel picture of school social work in 2013. WA: International Network for School Social Work.

Johnston, J., ve Zemitzsch, A. (1988). Family power: An intervention beyond the classroom. Behavioral Disorders, 14(1), 69-79. 
Kemper, E., S., S. and Teddlie, C. (2003). Mixed methods sampling strategies in social science research. İçinde C. A. Tashakk \& Teddlie (Ed.), Handbook of mixed methods in social \& behavioral research (p.273-296). Sage Publication.

Korkut, F. (2007). Psikolojik danışmanların mesleki rehberlik ve psikolojik danışmanlık ile ilgili düşünceleri ve uygulamaları. H.Ü. Eğitim Fakültesi Dergisi, 32, 187-197.

Lewis, W. (1996). A proposal for initiating family counseling interventions by school counselors. School Counselor, 44(2), 93-99.

Long, L. (1988). Providing assistance to latchkey families. Pointer, 33(1), 37-40.

Matejevic, M., Jovanovic, D. and Lazarevic, V. (2014). Functionality of family relationships and parenting style in families of adolescents with substance abuse problems. Procedia - Social and Behavioral Sciences, 128, 281-287. https://doi.org/10.1016/j.sbspro.2014.03.157

MEB. (2017). Miili Ĕ̆itim Bakanlı̆̆l Rehberlik Hizmetleri Yönetmeliği.

Pişkin, M. (2006). Türkiye' de psikolojik danışma ve rehberlik hizmetlerinin dünü, bugünü ve yarmı. Türkiye'de Eğitim Bilimleri: Bir bilanço denemesi. Ankara: Nobel Yay.

Rowling, L. (2009). Strengthening "school" in school mental health promotion. Health Education, 109(4), 357-368.

Smetana, J. and Gaines, C. (1999). Adolescentparent conflict in middle-class African American families. Child Development, 70, 1447-1463.

Tracy, E., Castro-Guillen, E. and Schraff, S. (2006). Roles of school and community providers in the delivery of school based mental health services. Effective Practice Integration Council, Center for School Based Mental Health Programs, Miami University of Ohio.

Walker, S. (2003). Social work and child mental health: psychosocial principles in community practice. British Journal of Social Work, 33(5), 673-687. https://doi.org/10.1093/bjsw/33.5.673

Wetchler, J. (1986). Family therapy of school-focused problems: A macrosystemic perspective. Contemporary Family Therapy, 8(3), 224-240.

Widerman, J. and Widerman, E. (1995). Family systems-oriented school counseling. School Counselor, 43(1), 66-73.

Yıldırım, A. ve Şimşek, H. (2016). Sosyal Bilimlerde nitel araştırma yöntemleri. Ankara: Seçkin yayınclik. 


\section{Kaynakça Bilgisi / Citation Information}

K1lıç Ceyhan, E. ve Özbesler, C. (2021). Anne baba ve ergenlerin gözüyle okul sosyal hizmet uygulamalarına duyulan ihtiyacin belirlenmesi. OPUS-Uluslararası Toplum Araştırmaları Dergisi, 18(Eğitim Bilimleri Özel Sayıs1), 4428-4452. DOI: 10.26466/opus.839688. 